\title{
Life Cycle Assessment Applied to Naphtha Catalytic Reforming
}

\author{
J.-F. Portha' ${ }^{1}$, J.-N. Jaubert ${ }^{1}$, S. Louret ${ }^{2}$ and M.-N. Pons ${ }^{1}$ \\ 1 Laboratoire Réactions et Génie des Procédés, CNRS-ENSIC-INPL, Nancy - France \\ 2 IFP Energies nouvelles-Lyon, Rond-point de l'échangeur de Solaize, BP 3, 69360 Solaize - France \\ e-mail: jean-francois.portha@ensic.inpl-nancy.fr - jean-noel.jauberł@ensic.inpl-nancy.fr - sylvain.loure@@ifpenergiesnouvelles.fr \\ marie.noelle.pons@ensic.inpl-nancy.fr
}

Résumé - Analyse de cycle de vie appliquée au reformage catalytique du naphta - Les considérations liées à l'environnement doivent de plus en plus être prises en compte par les ingénieurs et les scientifiques afin de juger de la durabilité des procédés chimiques dans l'industrie pétrolière et gazière. Parmi les différentes méthodes d'analyse environnementale, l'Analyse de Cycle de Vie (ACV) est très utilisée. Dans cette étude, l'ACV est appliquée au procédé de reformage catalytique du naphta en utilisant la méthode Eco-Indicateur 99 comme méthode d'analyse des impacts du cycle de vie. Les principaux impacts environnementaux du procédé sont la consommation de combustibles fossiles, le changement climatique et les effets sur la respiration liés aux composés organiques. L'influence de différents paramètres (composition de l'alimentation, température de réaction) sur les impacts environnementaux est testée. Deux méthodes d'allocation sont analysées (allocation massique et énergétique) et deux versions du procédé de reformage catalytique sont comparées afin de déterminer les améliorations possibles permettant de minimiser les impacts.

\begin{abstract}
Life Cycle Assessment Applied to Naphtha Catalytic Reforming - Facing the increase of environmental concerns in the oil and gas industry, engineers and scientists need information to assess sustainability of chemical processes. Among the different methods available, Life Cycle Assessment (LCA) is widely used. In this study, LCA is applied to a catalytic reforming process using the EcoIndicator 99 as life cycle impact assessment method. The main identified environmental impacts are fossil fuels consumption, climate change and respiratory effects due to inorganics compounds. The influence of different process parameters (feed composition, reaction temperature) is determined with respect to environmental impacts. Two allocation methods are analysed (mass and exergetic allocation) and two different process versions are compared in order to determine the effect of some improvements on environmental impact.
\end{abstract}




\section{NOMENCLATURE}

A Reactor section

$C_{p}^{0} \quad$ Specific heat capacity

$m_{i} \quad$ Mass flow rate of product $i$

$Q \quad$ Quality index

$Q_{m} \quad$ Mass flow rate

$r_{i} \quad$ Production rate of chemical reaction $i$

$r_{i, j} \quad$ Production rate of component $j$ in reaction $i$

$T$ Temperature

$z \quad$ Reactor abscissa

$\alpha_{i} \quad$ Monetary specific value of product $i$

$\Delta_{r} H_{i}^{0}$ Standard enthalpy of reaction $i$

$v_{i, j} \quad$ Stoichiometric coefficient of component $j$ in reaction $i$

$\mu \quad$ Partial molar Gibbs energy

$\rho \quad$ Catalyst density

\section{Abbreviations}

AETP Aquatic Ecotoxicity Potential

CCS $\quad \mathrm{CO}_{2}$ Capture and Storage

CFC Chlorofluorocarbon

DALY Disability Adjusted Life Years

ELCA Exergetic Life Cycle Assessment

EDF Electricité de France

GHG Greenhouse Gas

GWP Global Warming Potential

HCFC Hydrochlorofluorocarbon

IPCC Intergovernmental Panel on Climate Change

ISO International Organisation for Standardisation

LCA Life Cycle Assessment

LCI Life Cycle Inventory

LCIA Life Cycle Impact Assessment

LPG Liquefied Petroleum Gas

MJ Mega Joule

ON Octane Number

PDF Potentially Disappeared Fraction of species

PEC Predicted Environmental Concentration

PNEC Predicted No Environmental Concentration

RDF Refuse Derived Fuel

SETAC Society for Environmental Toxicology and Chemistry

TETP Terrestrial Ecotoxicity Potential

\section{INTRODUCTION}

In the current context, oil and gas industry processes have to be developed considering technical and economical issues but also sustainability. Climate change is one of the main environmental impacts because its consequences could be considerable in some decades. But other impacts such as resource depletion, eutrophication, toxicity and ozone layer depletion have also to be taken into account when different products or processes are compared. A classical method used to quantify the environmental impact of a process or a product is Life Cycle Assessment. In this method each step of the life cycle is considered and an indicator is calculated for each impact. In this work, Life Cycle Assessment is applied to a process from the oil and gas industry: the naphtha catalytic reforming process.

\section{LCA METHODOLOGY}

\subsection{System Life Cycle}

A system is the whole set of unit operations corresponding to a product, a process or an activity. The life cycle is the whole set of sequential phases comprised in a system from raw materials acquisition to disposal or recycling (from cradle to grave). Each step of life cycle (extraction and treatment of raw materials, energy conversions, transportation, distribution, waste disposal or recycling...) has an impact on environment and must be taken into account. If only a part of the chain is studied, what could appear as an environmental improvement on this part could lead to a worsening of the environmental impact on other upstream or downstream parts of the chain (Bouvart and Prieur, 2009). These pollution transfers can occur from one phase to another phase of the life cycle or from one impact to another impact.

\subsection{LCA Steps}

LCA is a tool used to evaluate environmental impact at each step of a system life cycle. This methodology has been developed from chemical engineering principles and is based on mass and energy balances. LCA has mainly been applied to products but it can be applied for process design, selection and optimisation (Azapagic, 1999), (Burgess and Brennan, 2001a). In 1990, the Society for Environmental Toxicology and Chemistry (SETAC) initiated activities to develop a methodology for LCA (Consoli et al., 1993). The International Organisation for Standardisation (ISO) started a similar work (Guinée et al., 2000). LCA is divided into four steps corresponding to a set of standardised ISO norms:

- Objectives and scope definition (ISO 14040, 2000),

- Life Cycle Inventory analysis (ISO 14041, 2000),

- Life Cycle Impact Assessment (ISO 14042, 2000),

- Improvement analysis (ISO 14043, 2000).

Its main benefit, over other site specific methods, is to include all burdens and impact in the life cycle of a product or a process, and not focusing on the emissions and wastes generated by the plant or manufacturing site only.

The first step of the study consists in precisely defining the goal of the work, because it determines the way to lead the analysis. For example, if processes should be compared, some life cycle phases could be eliminated because they could be identical in the processes under comparison. It is also important to set up boundaries. For that purpose, life 
cycle phases included in the analysis should be selected. It could be useful to consider the "foreground" and the "background" systems: the foreground system is defined as the set of processes delivering directly the functional unit and the background system is the system that provides the foreground system with energy and materials (Azapagic, 1999). The construction and dismantling phases, for a sufficiently long lifetime, can be neglected in the analysis (Lombardi, 2003). At this stage, the functional unit has to be defined. All functions performed by the system have to be known. The functional unit is a measure of the function that the system delivers. When several systems are considered, the same functional unit must be used to compare them.

The Life Cycle Inventory (LCI) phase involves identification of the unit operations included in the system. Data concerning the unit operations of the system are collected. Lab, pilot or plant scale data are collected and a computer model is used to determine the mass and energy input and output fluxes. Environmental impacts that would be dealt with are defined.

The Life Cycle Impact Assessment (LCIA) phase aims at the calculation of each impact reported in the inventory analysis. An appropriate impact indicator is used for each impact. Results can be aggregated to a global single indicator. The LCIA may include the classification of each impact to damage categories (classification), the modelling of environmental impacts with an impact indicator (characterisation) and optional elements. These optional elements depend on the scope of the study: normalisation of each impact to a reference value and weighting (i.e. allocation of weighting factors to each impact). Weighting in LCA has always been a controversial issue because weighting factors should be set based on social, political or economical values (Finnveden, 2006). Despite the controversies, weighting is widely used in practice. The LCIA method used in this study is EcoIndicator 99 (Goedkoop, 2000). This method is damagebased, meaning that the damage to human or ecosystem caused by environmental effects is modelled. Table 1 summarises the environmental impacts used in the Eco-Indicator 99 method. These environmental impacts are classified in three different damage categories (Goedkoop, 2000):

- human health damage, which are measured in Disability Adjusted Life Years (DALYs); damage of one means that one life year of one individual is lost;

- ecosystem quality damages, that are measured in PDF $\mathrm{m}^{2} \mathrm{yr}$ (potentially disappeared fraction of species); a damage of one means that all species disappear from a $\mathrm{m}^{2}$ over one year or $10 \%$ of all species disappear from $10 \mathrm{~m}^{2}$ over one year;

- damages to resources, which are measured in MJ of surplus energy; a damage of one means that further extraction of the same resources in the future will need an additional $\mathrm{MJ}$ of energy due to the lower resource concentration or other unfavourable characteristics of the remaining reserve.
The improvement analysis is the phase in which the results of the previous phases are analysed according to the scope of the study. The objective is to conclude and to improve the life cycle in order to give information to decision maker.

\section{TABLE 1}

Environmental impact description

\begin{tabular}{|c|c|}
\hline Environmental impact & Description \\
\hline Carcinogens & $\begin{array}{l}\text { Carcinogenic effects due to emissions of } \\
\text { carcinogenic substances to air, water and soil }\end{array}$ \\
\hline Respiratory organics & $\begin{array}{l}\text { Respiratory effects due to emissions of organic } \\
\text { substances to air }\end{array}$ \\
\hline Respiratory inorganics & $\begin{array}{l}\text { Respiratory effects due to dust, sulphur, } \\
\text { and nitrogen oxides to air }\end{array}$ \\
\hline Climate change & $\begin{array}{l}\text { Global warming due to greenhouse gas emissions } \\
\text { in atmosphere }\end{array}$ \\
\hline Radiation & Damage resulting from radioactive radiation \\
\hline Ozone layer depletion & $\begin{array}{l}\text { Damage due to increased UV radiation as a result } \\
\text { of emission of ozone depleting substances to air }\end{array}$ \\
\hline Ecotoxicity & $\begin{array}{l}\text { Damage to ecosystem quality as a result of } \\
\text { emission of toxic substances to air, soil and water }\end{array}$ \\
\hline Acidification & $\begin{array}{l}\text { Forest and lake destruction by acid rains due to } \\
\text { acid air emissions }\end{array}$ \\
\hline Eutrophication & $\begin{array}{l}\text { Lack of oxygen and algae development in water } \\
\text { streams or soil due to too high nitrogen and } \\
\text { phosphorous concentrations }\end{array}$ \\
\hline Land use & $\begin{array}{l}\text { Damage as a result of either conversion of land } \\
\text { or occupation of land }\end{array}$ \\
\hline Minerals & $\begin{array}{l}\text { Non renewable resource depletion due to } \\
\text { extraction and consumption of minerals }\end{array}$ \\
\hline Fossil fuels & $\begin{array}{l}\text { Non renewable resource depletion due to } \\
\text { extraction and consumption of fossil fuels }\end{array}$ \\
\hline
\end{tabular}

\subsection{Allocation of Co-products}

Allocation can be defined as the act of proportionally distributing the responsibility for resources consumption, emissions and waste streams between different co-products in a process. Each environmental impact should be allocated to each co-product. Different allocation methods exist. The international standard gives some guidance on how to handle allocation problems (Finnveden et al., 2009):

- subdivision or system expansion when possible;

- substitution method (avoided impact method) when possible;

- allocation reflecting physical, chemical or biological causations (for example energetic or exergetic pro rata);

- allocation based on other measures (for example mass or economical pro rata). 
The allocation method depends also on the system characteristics. For processes dealing with energy conversion, energetic or exergetic pro rata seems to be the best allocation mode because it reflects products value.

\section{APPLICATIONS}

There are not many references in literature describing the use of LCA to processes. We will here focus on works dealing with LCA applied to chemical processes, biofuels, recycling and renewable energy. Some examples are described in Table 2.

\section{TABLE 2}

Examples of LCA applied to chemical processes, biofuels, recycling and renewable energy

\begin{tabular}{l|l}
\hline Author & Process \\
\hline Burgess and Brennan (2001b) & Desulfurisation of gas oil \\
\hline Arena et al. (2003) & Waste management \\
\hline Chevalier et al. (2003) & Municipal solid waste incinerators \\
\hline Lombardi (2003) & Power generation systems \\
\hline Renou et al. (2008) & Wastewater treatment processes \\
\hline Bouvart and Prieur (2009) & $\begin{array}{l}\text { Combined hydrogen and electricity } \\
\text { production with integrated } \mathrm{CO}_{2} \text { capture } \\
\text { and storage }\end{array}$ \\
\hline Cherubini et al. (2009) & Biofuel and bioenergy systems \\
\hline Gebreslassie et al. (2009) & Absorption cooling systems \\
\hline Pehnt and Henkel (2009) & $\begin{array}{l}\text { Carbon dioxide capture and storage } \\
\text { from lignite power plant }\end{array}$ \\
\hline Stichnotte and Azapagic (2009) & Bioethanol routes \\
\hline
\end{tabular}

Burgess and Brennan (2001a) gave a review of LCA applied to chemical processes before 2001. Burgess and Brennan (2001b) outlined the importance of fugitive emissions in a desulphurization process of petroleum gasoil incorporating a hydrotreater unit, hydrogen plant and sulphur recovery unit.

Renou et al. (2008) studied wastewater treatment process and discuss the influence of the Life Cycle Impact Assessment method. They conclude that the impact assessment methods do not influence LCA results for most of the impacts. However, concerning local river eutrophication, LCA should be combined with microbial and chemical risk analysis. The management of Municipal Solid Wastes (MSW) was led by Arena et al. (2003): three scenarios were taken into account: landfilling, Refuse Derived Fuel (RDF) production and combustion and mass burn combustion. Different environmental impacts were quantified (material consumption, climate change, acidification, air and water emissions and solid waste production). Results showed the poor performance of landfilling option with respect to the other options. In the same field, two processes for flue gas of solid waste in municipal incinerators were studied by Chevalier et al. (2003). Several environmental impacts were calculated to compare a classical wet type process and a new transported droplets column process.

Power generation systems have been studied by Lombardi (2003). Three different configurations were compared by an Exergetic Life Cycle Assessment (ELCA) and a classical LCA to decrease greenhouse gas emissions. ELCA is an analysis method based on life cycle approach in combination with exergy analysis developed by Cornelissen (1997). Destroyed exergy is viewed as an impact indicator reflecting the depletion of natural resources. A review of different LCA and exergy coupled analysis is given in a previous publication (Portha et al., 2009) and was applied to naphtha catalytic reforming.

Cherubini et al. (2009) compared different biofuels sources and their impact on Greenhouse Gas (GHG) emissions. They conclude that bioenergy compared to their fossil reference can achieve a reduction of GHG emissions and fossil energy consumption but other environmental impacts (such as eutrophication and local air pollution) can be increased. LCA requires taking into account all environmental impact when biofuels routes are compared to classical fuel routes.

Stichnotte and Azapagic (2009) studied two bioethanol routes produced from two different feedstocks derived from household waste and show that GHG emissions decrease significantly for a given scenario but that a full life cycle approach has to be applied to take all impacts into account.

Bouvart and Prieur (2009) compared twelve scenarios concerning combined hydrogen and electricity production with and without $\mathrm{CO}_{2}$ Capture and Storage (CCS) for different feedstocks (natural gas, bituminous coal and lignite). The study was based on two main criteria: GHG emissions and non renewable primary energy consumption. A significant reduction of the GHG emissions (between 70 and $82 \%$ ) and a significant increase of the non renewable energy consumption were shown when CCS was used. Pehnt and Henkel (2009) led the same task for several lignite power plant technologies. The LCA included post combustion, pre combustion and oxyfuel capture processes transport and storage of the $\mathrm{CO}_{2}$. The results were the same as previously. For other environmental impacts, the results depend on the chosen technology.

The design of a sustainable absorption cooling system was provided by Gebreslassie et al. (2009). The total annualized cost and the environmental impact of the cycle were minimized by a multiobjective optimisation method. Authors outlined that a compromise has to be found between the economic performance and fossil fuel consumption (main impact of LCA in this case). 


\section{CATALYTIC REFORMING PROCESS}

Catalytic reforming is a chemical process used to convert naphtha (of low octane number) produced during petroleum refining, into high-octane number liquid products (Meyers, 1996) which are called reformates. Basically, the process redesigns the hydrocarbon molecules of the naphtha feed and performs aromatization. Alongside these reactions, cracking (breakage of large molecules into smaller ones) takes place. The process produces very significant amounts of hydrogen gas and some light co-products (fuel gas and liquefied petroleum gas). The process studied here is a typical continuous catalytic regeneration reforming process. Because of coke formation, this type of process (depicted in Fig. 1) is characterized by a continuous in situ regeneration of the catalyst in a special regenerator. The regeneration of catalyst by coke combustion is also a source of direct greenhouse gas emissions in the process.

The reactions taking place are globally endothermic. The reaction section is split into four catalytic reactors. To maintain an appropriate temperature, between each reactor, a furnace heats the feed back up to the desired temperature. Each reactor inlet temperature is around $500^{\circ} \mathrm{C}$ and pressure is around 5 bar. Reactors are moving bed catalytic reactors with a Pt-Sn/ $/ \mathrm{Al}_{2} \mathrm{O}_{3}$ catalyst. Flash distillations and an atmospheric distillation column enable to separate products in the separation section. Catalyst regeneration is not represented in Figure 1 because the figure would be unreadable.

Two processes having the same function are considered in this study in order to be compared:

- the basic process (Process 1) described in Figure 1;

- the modified process (Process 2) corresponding to the basic process with two changes: for feed/effluent heat exchanger E1, a high performance heat exchanger is used instead of a classical one and a recycle loop is added to recycle Fuel Gas in order to have more LPG (a product having a higher price).

The vapor/liquid equilibria are calculated according to the Grayson-Streed thermodynamic model. The kinetic model used to represent chemical reactions taking place in reactors is based on the work by Marin and Froment (1981) and by Van Trimpont et al. (1988). The mechanism involves the following reactions: isomerisation, paraffins ring closure, naphthenes dehydrogenation and hydrocracking. The petroleum cuts $\mathrm{C} 6, \mathrm{C} 7, \mathrm{C} 8, \mathrm{C} 9$ and $\mathrm{C} 10$ (number of carbon atoms of the component) contained in the feed are taken into account for chemical reactions. For petroleum cut C7, the chemical reactions are described in Table 3.

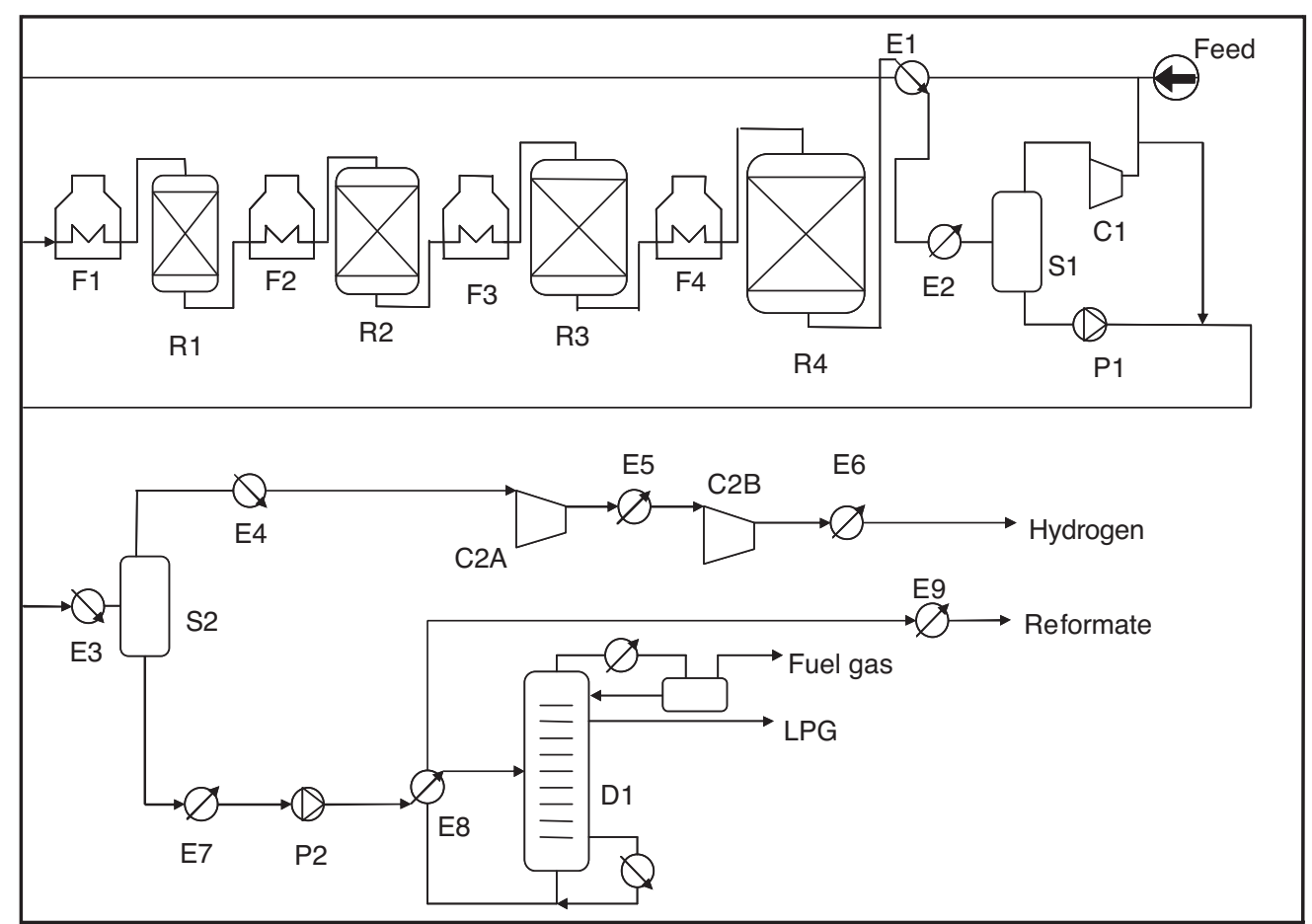

Figure 1

Flow sheet of the reforming process (E: heat exchanger, F: furnace, R: reactor, P: pump, C: compressor, D: distillation column, S: flash distillation). 
TABLE 3

Chemical reaction for the petroleum cut $\mathrm{C} 7$

\begin{tabular}{c|c}
\hline Chemical reaction & Name \\
\hline $\mathrm{nC7} \rightleftarrows \mathrm{iC7}$ & Isomerisation \\
\hline $\mathrm{iC7} \rightleftarrows \mathrm{N} 7+\mathrm{H}_{2}$ & Ring closure \\
\hline $\mathrm{N} 7 \rightleftarrows \mathrm{A} 7+3 \mathrm{H}_{2}$ & Dehydrogenation \\
\hline $\mathrm{iC} 7 \rightarrow \mathrm{C}^{-}$ & Hydrocracking \\
\hline
\end{tabular}

The process is simulated with the process simulator ProII 8.0 (Simscii, Lake Forest, Illinois) coupled with a Fortran subroutine for reactor calculation. Plug flow is assumed in the reactors. Under these conditions, a mass balance has been applied for each component $j$ of the mixture involved in chemical reaction $i$ and is given by Equation (1):

$$
\frac{d F_{j}}{d z}=\left(\sum_{i} v_{i, j} r_{i, j}\right) \rho A
$$

with $F_{j}$ : molar flow rate of component $j\left(\mathrm{~mol} . \mathrm{s}^{-1}\right), z$ : reactor abscissa (m), $v_{i, j}$ : stoichiometric coefficient of component $j$ in reaction $i, r_{i, j}$ production rate of component $j$ in reaction $i$ $\left(\right.$ mol. $\left.\mathrm{kg}^{-1} \cdot \mathrm{s}^{-1}\right), \rho$ : catalyst density $\left(\mathrm{kg} \cdot \mathrm{m}^{-3}\right)$ and $A$ : reactor section $\left(\mathrm{m}^{2}\right)$.

A global heat balance has also been applied and is given by Equation (2):

$$
\frac{d T}{d z}=-\frac{\rho A}{Q_{m} C_{p}^{0}(T)}\left(\sum_{i} r_{i} \Delta_{r} H_{i}^{0}(T)\right)
$$

with $T$ : temperature $(\mathrm{K}), Q_{m}$ : mass flow rate $\left(\mathrm{kg} . \mathrm{s}^{-1}\right), C_{p}^{0}$ : specific heat capacity $\left(\mathrm{J} \cdot \mathrm{kg}^{-1} \cdot \mathrm{K}^{-1}\right), r_{i}$ : production rate of chemical reaction $i\left(\mathrm{~mol}_{\mathrm{kg}} \mathrm{kg}^{-1} \mathrm{~s}^{-1}\right)$, and $\Delta_{r} H_{i}^{0}$ : standard enthalpy of reaction $i\left(\mathrm{~J}_{\mathrm{kg}} \mathrm{kg}^{-1}\right)$.

The differential equations system is solved for each reactor by a Runge-Kutta method. Results have been validated by comparison with full scale industrial data. Numerical information obtained from simulations of the studied processes is given in Table 4 .

TABLE 4

Mass and energetic flow rates for Process 1 and Process 2 (Naphtha $1, T=810 \mathrm{~K}$ )

\begin{tabular}{c|c|c}
\hline & Process 1 & Process 2 \\
\hline Feed $\left(\mathrm{kg} \cdot \mathrm{h}^{-1}\right)$ & 60605 & 60605 \\
\hline Hydrogen $\left(\mathrm{kg} \cdot \mathrm{h}^{-1}\right)$ & 4218 & 4218 \\
\hline Fuel Gas $\left(\mathrm{kg} \cdot \mathrm{h}^{-1}\right)$ & 104 & 6 \\
\hline LPG $\left(\mathrm{kg} \cdot \mathrm{h}^{-1}\right)$ & 633 & 731 \\
\hline Reformate $\left(\mathrm{kg} \cdot \mathrm{h}^{-1}\right)$ & 55650 & 55650 \\
\hline Electricity $(\mathrm{MW})$ & 4.08 & 4.08 \\
\hline Heat duty $(\mathrm{MW})$ & 24.57 & 24.13 \\
\hline
\end{tabular}

\section{CHARACTERISTICS OF THE LCA APPLIED TO THE PROCESS}

The functional unit is the production of one $\mathrm{kg}$ of reformate. The quality of the produced reformate should be the same for each comparison. However, in any oil and gas process, the quality of the product is never the same because it depends on the crude oil. To check the quality of reformate, the octane number and the quality index of all co products will be given. The quality index has been defined in a previous paper (Portha et al., 2009):

$$
Q=\sum_{i=1}^{p} \alpha_{i} m_{i}
$$

with $Q$ : quality index $(€ / \mathrm{h}), \alpha_{i}$ : monetary specific value of product $i(€ / \mathrm{kg}), m_{i}$ : mass flow rate of product $i(\mathrm{~kg} / \mathrm{h})$.

The boundaries of the system include utility production (electricity and heat generation and distribution) and the catalytic reforming process itself. In our specific case, natural resources extraction, transport operations and crude oil distillation have been excluded because the same feed is supplied to the tested reforming processes which means that these contributions cancelled out when they are compared.

As stated in the literature, construction and dismantling phases can be neglected because the lifetime of a refinery is at least 40 years so that the operation phase is the most important. The catalyst production and destruction are also negligible phases. The LCA boundaries are described in Figure 2.

The catalytic reforming process used for simulations has been described previously. The feed corresponds to naphtha produced in European refineries. The electricity mix used for calculations is the French one with a large part of nuclear origin (Tab. 5). Heat is produced in natural gas furnaces with a low $\mathrm{NO}_{\mathrm{X}}$ technology. All data concerning mass and heat fluxes are calculated as previously described. Chemicals, electricity and heat production inventories were taken from Simapro 6 database.

\section{TABLE 5}

Source of French electricity production in 2008 (primary energy sources) (source: EDF)

\begin{tabular}{c|c}
\hline Source of french electricity & $\%$ \\
\hline Nuclear & 82.9 \\
\hline Hydroelectricity & 7.5 \\
\hline Fuel & 1.4 \\
\hline Natural Gas & 3.0 \\
\hline Coal & 3.1 \\
\hline Other renewable energy & 1.8 \\
\hline Other & 0.3 \\
\hline
\end{tabular}




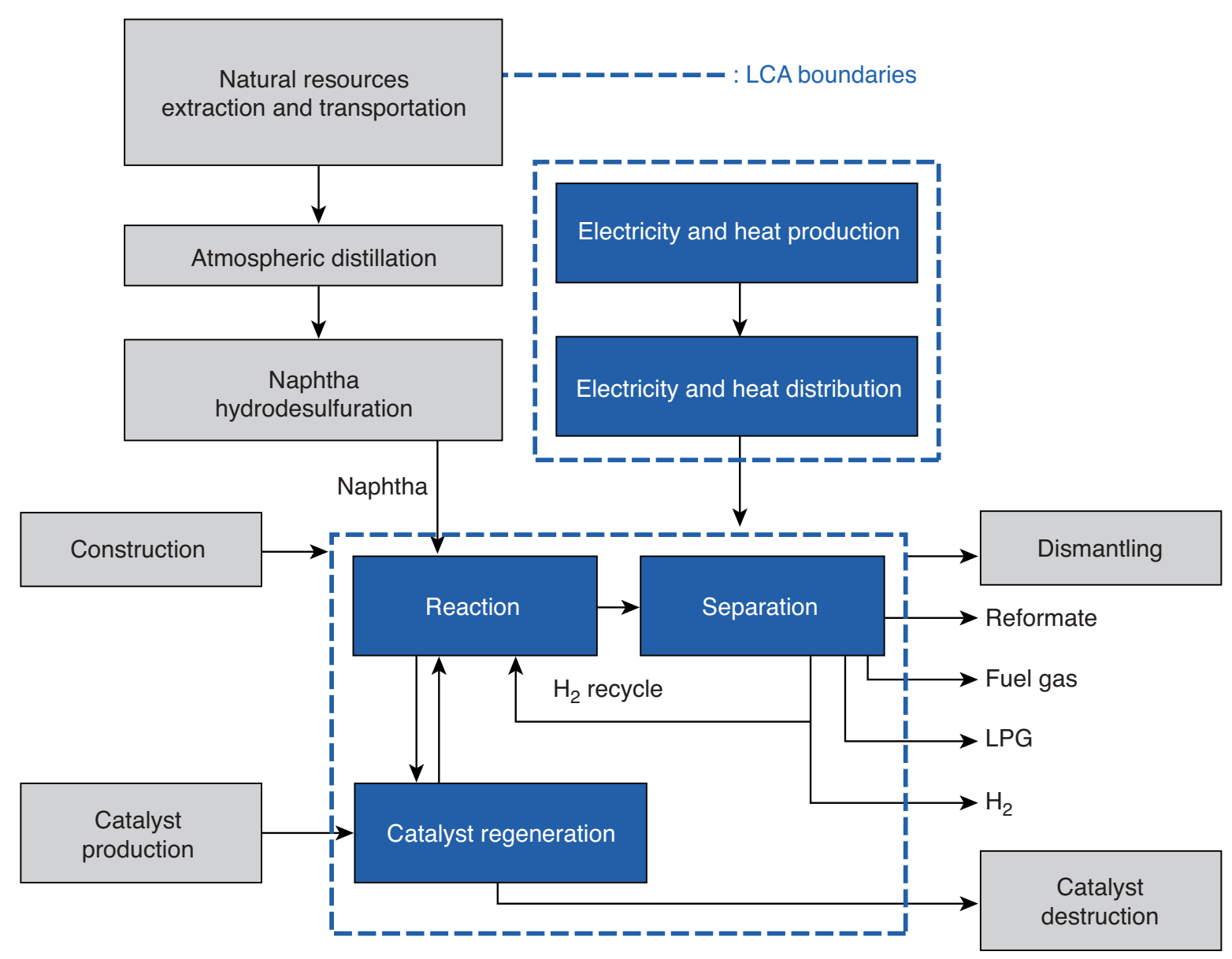

Figure 2

LCA boundaries.

For the LCIA step, the Eco-Indicator 99 method is used. It applies a damage oriented approach meaning that the damage to human or ecosystem caused by environmental effects is modelled. At the characterisation step, eleven impacts are considered: acidification, eutrophication, ozone layer depletion, greenhouse effect, resource depletion... The damage assessment step reduces these impacts into three damage categories: human health, ecosystem quality, and resources. Impacts and damage categories are presented in Table 6. Human health presents one major drawback as it contains impacts such as climate change that do not concern directly human toxicity.

The characterisation factors are described in Table 7.

For instance, the characterisation factors for different greenhouse gases are given in Table 8 . The considered factor is the global warming potential calculated over 100 years and defined by the IPCC (2007).
TABLE 6

Damage analysis (Eco-Indicator 99)

\begin{tabular}{|c|c|c|c|}
\hline Number & Impact category & Damage category & Unit \\
\hline 1 & Carcinogens & \multirow{6}{*}{$\begin{array}{l}\text { Damage to } \\
\text { human health }\end{array}$} & DALY \\
\hline 2 & Respiratory organics & & DALY \\
\hline 3 & Respiratory inorganics & & DALY \\
\hline 4 & Climate change & & DALY \\
\hline 5 & Radiation & & DALY \\
\hline 6 & Ozone layer depletion & & DALY \\
\hline 7 & Ecotoxicity & \multirow{3}{*}{ Damage to ecosystems } & PDF $\mathrm{m}^{2} \mathrm{yr}$ \\
\hline 8 & $\begin{array}{l}\text { Acidification/ } \\
\text { Eutrophication }\end{array}$ & & PDF $\mathrm{m}^{2} \mathrm{yr}$ \\
\hline 9 & Land use & & PDF $\mathrm{m}^{2} \mathrm{yr}$ \\
\hline 10 & Minerals & \multirow{2}{*}{ Damage to resources } & MJ surplus \\
\hline 11 & Fossil fuels & & MJ surplus \\
\hline
\end{tabular}


TABLE 7

Characterisation factors

\begin{tabular}{|c|c|c|c|c|}
\hline Impact category & Indicator & Model & Characterisation factor & Unit \\
\hline Depletion of abiotic resources & Ultimate reserve & Guinee and Heijungs 95 & Abiotic Depletion Potential (ADP) & $\mathrm{kg} \mathrm{Sb}$ eq \\
\hline Climate change & Infrared radiative forcing & IPCC & Global Warming Potential (GWP) & $\mathrm{kg} \mathrm{CO}_{2}$ eq \\
\hline Stratospheric ozone depletion & Stratospheric ozone breakdown & $\begin{array}{l}\text { World Meteorological } \\
\text { Organisation }\end{array}$ & Ozone Depletion Potential (ODP) & kg CFC11 eq \\
\hline Human toxicity & $\begin{array}{l}\text { Predicted daily intake } \\
\text { Accepted daily intake }\end{array}$ & $\begin{array}{l}\text { EUSES, California } \\
\text { toxicology model }\end{array}$ & $\begin{array}{c}\text { Human Toxicity Potential } \\
\text { (HTP) }\end{array}$ & $\mathrm{kg} 1,4 \mathrm{DCB}$ eq \\
\hline Ecotoxicty & PEC, PNEC & EUSES & AETP, TETP, etc. & $\mathrm{kg} \mathrm{1,4} \mathrm{DCB} \mathrm{eq}$ \\
\hline Photo oxidant formation & Tropospheric ozone production & $\begin{array}{l}\text { UNECE trajectory } \\
\text { model }\end{array}$ & $\begin{array}{c}\text { Photochemical Ozone } \\
\text { Creation Potential (POCP) }\end{array}$ & $\mathrm{kg} \mathrm{C}_{2} \mathrm{H}_{6}$ eq \\
\hline Acidification & Deposition/critical load & RAINS model & Acidification Potential (AP) & $\mathrm{kg} \mathrm{SO}_{2}$ eq \\
\hline Eutrophication & Deposition/critical load & $\begin{array}{l}\text { Stoichiometric procedure } \\
\text { of Heijungs (1994) }\end{array}$ & Eutrophication Potential (EP) & $\mathrm{kg} \mathrm{PO}_{4}$ eq \\
\hline
\end{tabular}

TABLE 8

Global Warming Potential over 100 years $\left(\mathrm{GWP}_{100}\right)$ (source: IPCC, 2007)

\begin{tabular}{c|c|c|c}
\hline Greenhouse gas & $\begin{array}{c}\text { Chemical } \\
\text { formula }\end{array}$ & $\begin{array}{c}\text { Lifetime } \\
\text { (years) }\end{array}$ & $\mathrm{GWP}_{100}$ \\
\hline Water & $\mathrm{H}_{2} \mathrm{O}$ & $\sim 0.04$ & - \\
\hline Carbon dioxide & $\mathrm{CO}_{2}$ & 100 & 1 \\
\hline Methane & $\mathrm{CH}_{4}$ & 12 & 25 \\
\hline Nitrous oxide & $\mathrm{N}_{2} \mathrm{O}$ & 114 & 298 \\
\hline $\begin{array}{c}\text { Halocarbons } \\
\text { (CFC, HCFC) }\end{array}$ & - & $0.7-1700$ & $5-14400$ \\
\hline Hydrofluorocarbons & $\mathrm{C}_{x} \mathrm{H}_{y} \mathrm{~F}_{\mathrm{z}}$ & $1.4-270$ & $124-14800$ \\
\hline $\begin{array}{c}\text { Perfluorinated } \\
\text { compounds }\end{array}$ & $\mathrm{SF}_{6}, \mathrm{NF}_{3}, \mathrm{CF}_{4}, \mathrm{C}_{2} \mathrm{~F}_{6} \ldots$ & $740-50000$ & $7390-22800$ \\
\hline
\end{tabular}

To show in what extent an impact category has a significant contribution, the normalisation step is used. Results from impacts characterisation are divided by an inhabitant equivalent (environmental effects that an average European causes in a year). In the weighting step, some impacts are considered to be more important by the decision makers. Weighting factors are also allocated to environmental impacts. Results presented in the next part take into account this last step.

\section{RESULTS}

In this paragraph, all results given in Figures 3-6 are also reported in Appendix in the form of tables.

\subsection{Influence of Temperature}

The inlet temperature range of a furnace is comprised between $497^{\circ} \mathrm{C}(770 \mathrm{~K})$ and $537^{\circ} \mathrm{C}(810 \mathrm{~K})$. The inlet temperature of a furnace is identical for each furnace for a given simulation. The temperature level has a direct impact on the quality of reformate and on the quantity of energy used in a furnace. Increasing the temperature means that the quantity of aromatic products and the octane number are higher. But it means also that utility consumption increases and that the corresponding environmental impacts are greater. This result is described in Figure 3. The value of an environmental impact is given in milli-Eco-Indicator points. Numbers on the abscissa axis correspond to the different impacts described in Table 5. An increase of the inlet temperature involves an increase of all environmental impacts. In this figure, the main impact is fossil fuels consumption ( $88.3 \%$ of the total). Fossil fuels are used especially to produce heat in natural gas furnaces. The others significant impacts are climate change $(4.5 \%)$, respiratory effects due to inorganics $(3.4 \%)$ and land use $(2.2 \%)$.

The temperature increase implies an increase of reformate octane number and an increase of the quality factor (including all co products). The scenarios comparison presents difficulties because the functional unit (quality of reformate) is changed when temperature is modified. The comparison is possible when normalisation is performed by dividing the total environmental impact by the reformate octane number. This shows that the process working at $T=770 \mathrm{~K}$ presents the lower environmental impact for a given octane number.

The naphtha production life cycle is here not taken into account because the aim of the work is to compare different process conditions. This is a good assumption when the same 


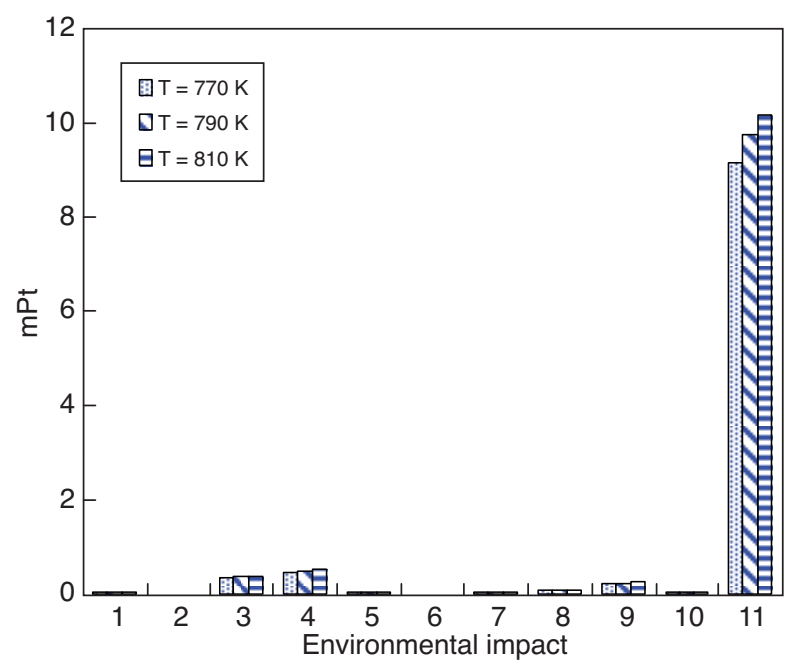

Figure 3

Temperature influence on environmental impacts for $1 \mathrm{~kg}$ reformate (Process 1, naphtha 1, mass allocation).

quantity of reformate is produced for a given quantity of naphtha feed. The quantity of feed is always identical. But, as presented in Table 9, the quantity of reformate decreases when the temperature increases. So, strictly speaking, the naphtha production life cycle should be taken into account in the analysis.

TABLE 9

Temperature influence on products quality for $1 \mathrm{~kg}$ of reformate (Process 1, naphtha 1)

\begin{tabular}{c|c|c|c}
\hline Temperature $(\mathrm{K})$ & 770 & 790 & 810 \\
\hline Octane number $(\mathrm{ON})$ & 88.3 & 92.7 & 96.4 \\
\hline Quality factor $\left(€ . \mathrm{h}^{-1}\right)$ & 21889 & 23229 & 24602 \\
\hline Reformate quantity $\left(\mathrm{kg} \cdot \mathrm{h}^{-1}\right)$ & 57858 & 56940 & 55650 \\
\hline Total environmental impact $(\mathrm{mPt})$ & 10.37 & 11.07 & 11.51 \\
\hline
\end{tabular}

\subsection{Distribution of the Environmental Impact between the Life Cycle Steps}

The life cycle phases that contribute to the three main environmental impacts in our case study (fossil fuels consumption, climate change and respiratory effects due to inorganics) are presented in Figure 4. For each impact, the main contribution is due to the heat produced in natural gas industrial furnaces. Electricity represents less than $25 \%$ because it corresponds to the French electricity mix with a large part of nuclear energy (Tab. 5), which does not affect fossil fuels consumption and climate change.

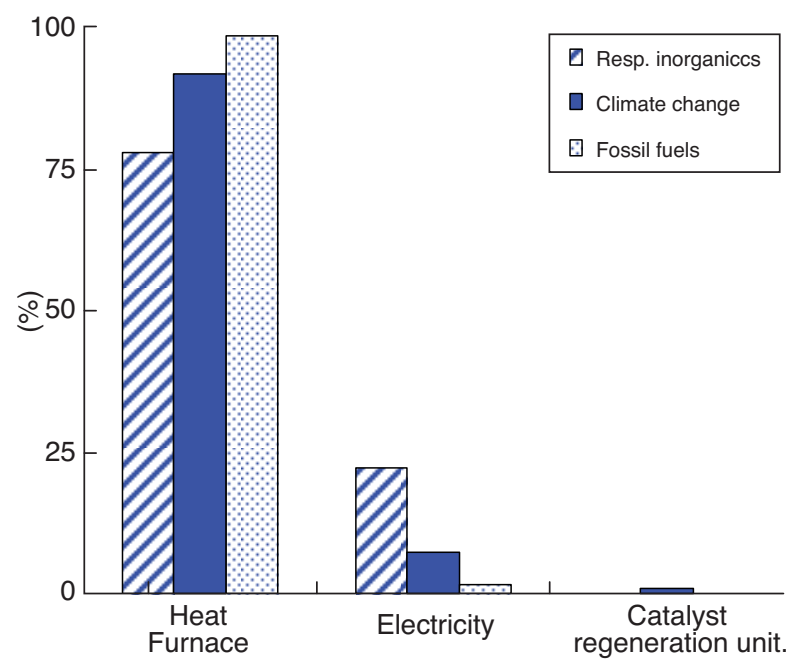

Figure 4

Assignment of the three main environmental impacts (Process 1, $T=810 \mathrm{~K}$, naphtha 1, mass allocation).

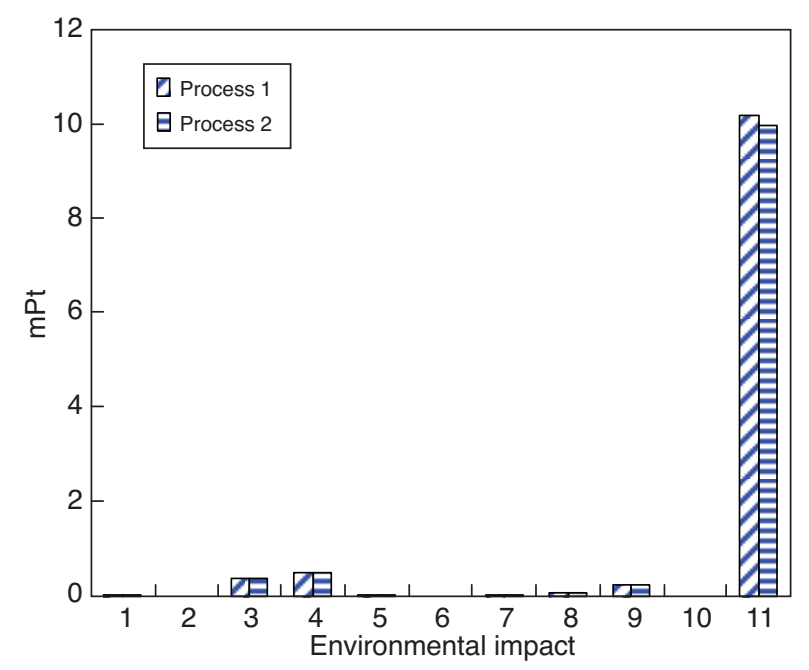

Figure 5

Process influence on environmental impacts for $1 \mathrm{~kg}$ of reformate ( $T=810 \mathrm{~K}$, naphtha 1 , mass allocation).

The direct emissions (greenhouse gas emissions of $\mathrm{CO}_{2}$ ) taking place in the process itself are induced by the catalyst regeneration unit (by coke combustion) but it represents only $0.8 \%$ of the total impact of climate change. Concerning this impact, the contribution of heat furnaces and electricity represents respectively $91.9 \%$ and $7.3 \%$.

\subsection{Process Comparison}

The two compared processes have been described previously (Sect. 3). The environmental impacts associated with both processes are given in Figure 5. Fossil fuels consumption 
represents the main environmental impact. The global environmental impact (sum of all impacts) presents a decrease of $1.77 \%$ for process 2 with respect to process 1 . This result was expected because the high performance heat exchanger enables a saving of fossil fuels.

The comparison is here possible because the octane number is the same in both processes as shown in Table 10. The global quality index of co products is higher for process 2 because the recycle loop involves a higher production of LPG (a product having a better monetary value).

TABLE 10

Process influence on products quality for $1 \mathrm{~kg}$ of reformate

\begin{tabular}{c|c|c}
\hline Process & 1 & 2 \\
\hline Octane number & 96.4 & 96.4 \\
\hline Quality factor $\left(€ \cdot \mathrm{h}^{-1}\right)$ & 24602 & 24616 \\
\hline
\end{tabular}

\subsection{Influence of Feed}

Processes are simulated by using six different feeds. The feed composition is given in Table 11. The feed is a heavy gasoline cut from the atmospheric distillation unit. It contains hydrocarbon chains with six, seven, eight, nine or ten carbon atoms. It is mainly composed of paraffins and naphthenes and has also a low octane number. The feed composition depends on crude oil geographic origin.

TABLE 11

Feeds molar composition

\begin{tabular}{c|c|c|c|c|c|c}
\hline Naphtha & 1 & 2 & 3 & 4 & 5 & 6 \\
\hline n-paraffin & 19.0 & 24.7 & 27.2 & 28.6 & 18.5 & 16.7 \\
\hline iso-paraffin & 23.7 & 31.6 & 39.4 & 36.4 & 23.5 & 21.3 \\
\hline naphtenes & 41.6 & 30.5 & 19.8 & 20.0 & 34.0 & 52.0 \\
\hline aromatic & 15.7 & 13.2 & 13.7 & 15.0 & 24.0 & 10.0 \\
\hline
\end{tabular}

The results, presented in Figure 6, show that, for each feed, the process 2 has a lower impact than process 1 . Here the naphtha life cycle should be included in the analysis. But as the impact of the feed composition on chemical reactions was investigated in this study the naphtha pathway was not considered. Moreover, even if the flow rate of naphtha 3 is very high with respect to the others, the simulations can be compared because the reformate/naphtha ratio is almost constant (Tab. 12). The results show that an increase of iso paraffins involves a decrease of the global environmental impact. This could be explained by the fact that iso paraffins are favourably converted by exothermic cracking reactions. This implies that heat supplied by furnaces should be lower. But a high proportion of iso paraffins means also a low

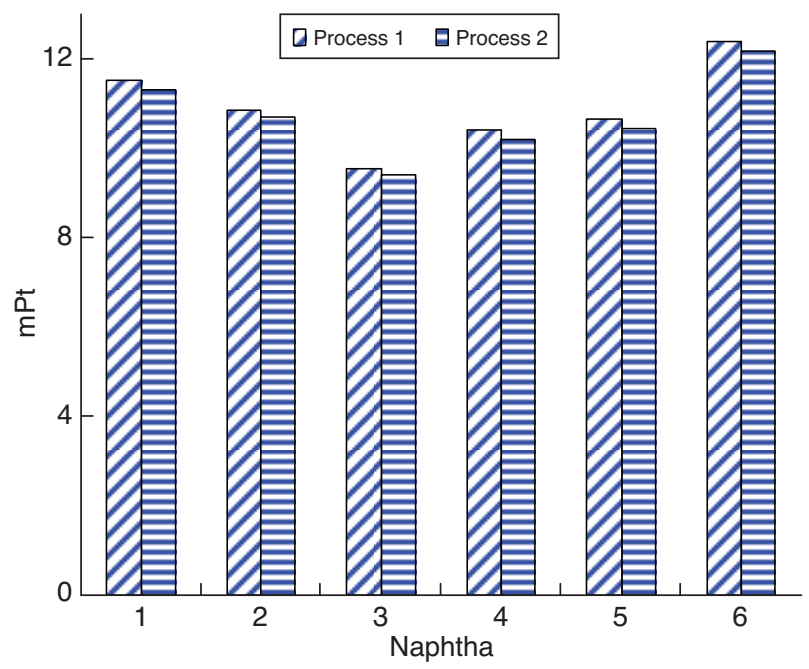

Figure 6

Feed influence on environmental impacts for $1 \mathrm{~kg}$ of reformate ( $T=810 \mathrm{~K}$, mass allocation).

reformate octane number (Tab. 12). The other significant parameter is the proportion of naphthenes. An increase of naphthenes involves an increase of the global environmental impact associated with an increase of the octane number (for instance for Naphtha 1 and 6). Naphthenes are converted by endothermic dehydrogenation reaction into aromatics. This implies that heat supplied by furnaces should be higher when the naphthenes proportion is high. The octane number is also high. It is the case for instance for Naphtha 6.

Finally, production of reformate with low octane number leads to a low total environmental impact. The required specification to produce gasoline with a high octane number is also not reached, so the environmental impact is just

TABLE 12

Feed influence on products quality for $1 \mathrm{~kg}$ of reformate (Process 1, $T=810 \mathrm{~K}$ )

\begin{tabular}{c|c|c|c|c|c|c}
\hline Naphtha & 1 & 2 & 3 & 4 & 5 & 6 \\
\hline Naphtha $\left(\mathrm{kg} \cdot \mathrm{h}^{-1}\right)$ & 60605 & 59612 & 91122 & 60897 & 59528 & 59525 \\
\hline $\begin{array}{c}\text { Reformate flow } \\
\text { rate }\left(\mathrm{kg} . \mathrm{h}^{-1}\right)\end{array}$ & 55650 & 54202 & 82947 & 55158 & 54828 & 54704 \\
\hline $\begin{array}{c}\text { Reformate/ } \\
\text { Naphtha ratio (\%) }\end{array}$ & 91.8 & 90.9 & 91.0 & 90.6 & 92.1 & 91.9 \\
\hline \begin{tabular}{c} 
Octane Number (ON) \\
\hline $\begin{array}{c}\text { Quality factor/ } \\
\text { reformate flow } \\
\text { rate (€.kg }\end{array}$
\end{tabular} & 96,4 & 93,2 & 87,1 & 91,5 & 98,3 & 95,9 \\
\hline $\begin{array}{c}\text { Total environmental } \\
\text { impact (mPt) }\end{array}$ & 11.5 & 10.9 & 9.6 & 10.4 & 10.6 & 12.4 \\
\hline
\end{tabular}


exported. Indeed, when specification is not met at the outlet of this specific process, actions should be undertaken, for example refining in another unit to reach the specification needed for use of gasoline.

\subsection{Influence of the Allocation Method}

Two allocation methods are applied to the studied system: mass pro rata and exergetic pro rata (physical and chemical exergy are taken into account). The expressions of exergy are given in previous works (Portha et al., 2008, 2009). The mass and exergetic percentages are given in Table 13. The reformate represents almost $92 \%$ in mass of the total mass of co products but only $86 \%$ when exergy is used to allocate co products. This is due to the high exergetic value per mass of hydrogen. This result is also true for energy.

TABLE 13

Mass and exergetic pro rata for co products

\begin{tabular}{c|c|c}
\hline & Mass allocation (\%) & Exergetic allocation (\%) \\
\hline Reformate & 91.8 & 86.0 \\
\hline Hydrogen & 7.0 & 12.7 \\
\hline LPG & 1.0 & 1.1 \\
\hline Fuel Gas & 0.2 & 0.2 \\
\hline
\end{tabular}

The results presented in Figure 7 show that the exergetic allocation implies a decrease of the impacts relative to reformate. This was expected because the proportion of reformate is lower for exergetic allocation than for mass allocation. The reformate has also a different impact

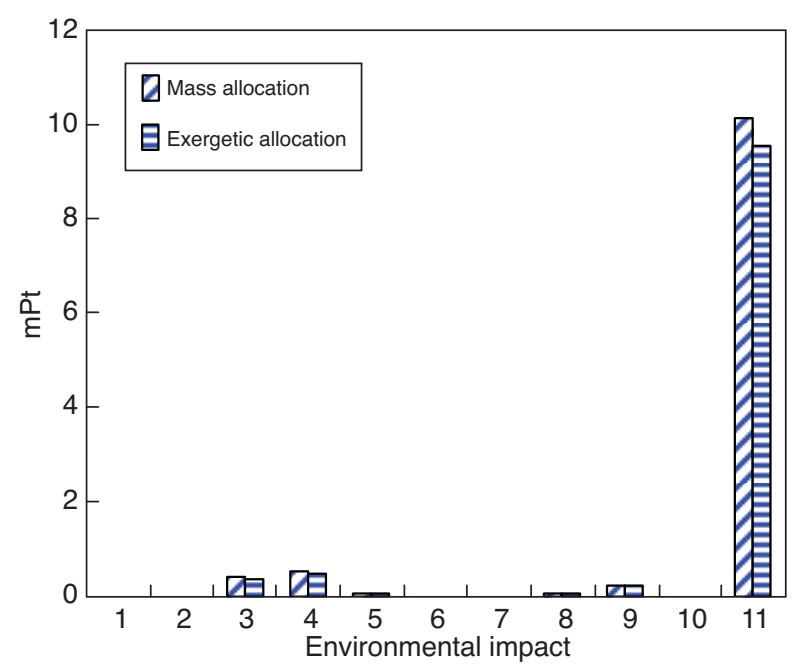

Figure 7

Allocation method influence on environmental impacts for $1 \mathrm{~kg}$ of reformate (Process $1, T=810 \mathrm{~K}$, naphtha 1 ). depending on whether exergetic or mass allocation is considered.

The substitution method was applied for one impact: climate change. This method consists in allocating all GHG emissions to the main product. After a calculation of the GHG emissions of the co-products produced by alternative processes, these emissions are summed. The difference between these two quantities gives the GHG emissions of the main product. The considered alternative pathway for hydrogen production was methane reforming. The contributions of other co-products were neglected. The results with this allocation method are presented in Table 14. Results show that reformate produced by catalytic reforming implies a saving of GHG emissions. This result is explained by the fact that catalytic reforming is the best process, from a sustainability point of view, to produce hydrogen.

\section{TABLE 14}

Allocation method influence on climate change for $1 \mathrm{~kg}$ reformate (Process $1, T=810 \mathrm{~K}$, naphtha 1 )

\begin{tabular}{c|c}
\hline Allocation method & GHG emissions relative to $1 \mathrm{~kg}$ reformate $\left(\mathrm{g}_{\mathrm{eq}} \mathrm{CO}_{2}\right)$ \\
\hline Mass & 123.1 \\
\hline Exergetic & 115.1 \\
\hline Substitution & -745.5 \\
\hline
\end{tabular}

\section{CONCLUSION}

Life Cycle Assessment is an interesting tool for chemical engineering. It provides information about process sustainability which is a relevant criterion for process selection and design. This tool is widely used in literature in different fields. A naphtha catalytic reforming process has been selected and evaluated by LCA using the Eco-Indicator 99 method. This methodology shows that the main environmental impacts are fossil fuels consumption, climate change and respiratory effects due to inorganics. The main contribution in terms of unit operation is due to the heat furnaces. The comparison performed to analyze two versions of the process displays that an addition of a high performance heat exchanger and a recycle loop to improve products quality are beneficial to decrease environmental impacts. Temperature and feed composition influence on environmental impacts were investigated: an increase of reactor temperature implies an increase of the impacts due to the endothermic chemical reactions; an increase of the iso-paraffins/n-paraffins ratio involves a decrease of environmental impacts because isoparaffins are easily converted by exothermic cracking reaction; an increase of the naphthenes/aromatics ratio leads to a increase of the impacts because naphthenes are converted by endothermic dehydrogenation reactions. The quality of the obtained products is a relevant parameter because the 
functional unit is defined with respect to a reformate having a given quality. In chemical processes, this is a complicated task because the compositions of crude oil and process parameters (temperature, pressure...) have an impact on composition and quality of the products.

\section{REFERENCES}

Arena U., Mastellone M.L., Perugini F. (2003) The environment performance of alternative solid waste management options: a life cycle assessment study, Chem. Eng. J. 96, 207-222.

Azapagic A. (1999) Life cycle assessment and its application to process selection, design and optimization, Chem. Eng. J. 73, 1-21.

Bouvart F., Prieur A. (2009) Comparison of life cycle GHG Emissions and energy consumption of combined electricity and $\mathrm{H}_{2}$ production pathways with CCS: selection of technologies with natural gas, coal and lignite as fuel for the European HYPOGEN programme, Energy Procedia 1, 3779-3786.

Burgess A.A., Brennan D.J. (2001a) Application of life cycle assessment to chemical process, Chem. Eng. Sci.56, 2589-2604.

Burgess A.A., Brennan D.J. (2001b) Desulfurisation of gas oil, a case study in environmental and economic assessment, J. Cleaner Prod. 9, 465-472.

Cherubini F., Bird N.D., Cowie A., Jungmeier G., Schlamadinger B., Woess-Gallasch S. (2009) Energy- and greenhouse gas-based LCA of biofuel and bioenergy systems: Key issues, ranges and recommendations, Resour. Conserv. Recy. 53, 434-447.

Chevalier J., Rousseaux P., Benoit V., Benadda B. (2003) Environmental assessment of flue gas cleaning processes of municipal solid waste incinerators by means of life cycle assessment approach, Chem. Eng. Sci. 58, 2053-2064.

Chevalier J. (1999) Elaboration of a protocol for processes life cycle assessment (in French), PhD Thesis, Institut National des Sciences Appliquées Lyon, France.

Consoli F., Allen D., Boustead I., Fava J., Frankilin W., Jensen A.A., De Oude N., Parrish R., Perriman R., Postletwaite D., Quay B., Siéguin J., Vignon B. (1993) Guidelines for life cycle assessment. A code of practice, SETAC Press, Pensacola, Florida.

Cornelissen R.L. (1997) Thermodynamics and sustainable development, the use of exergy analysis and the reduction of irreversibility, PhD Thesis, Enschede, The Netherlands.

Finnveden G., Eldth P., Johansson J. (2006) Weighting in LCA based on ecotaxes - development of a mid-point method and experiences from case studies, Int. J. LCA 11, 81-88.

Finnveden G., Hauschild M.Z., Ekvall T., Guinée J., Heijungs R., Hellweg S., Koehler A., Pennington D., Suh S. (2009) Recent developments in life cycle assessment, J. Environ. Manage. (in press).

Gebreslassie B.H., Guillen-Gosalbez G., Jimenez L., Boer D. (2009) Design of environmentally conscious absorption cooling systems via multiobjective optimization and life cycle assessment, Appl. Energ. 86, 1712-1722.

Goedkoop M., Spriensma R. (2000) The Eco Indicator 99 - A damage oriented method for life cycle impact assessment, Methodology report, 2nd edition, Pré Consultants, BV Amersfoort, The Netherlands.
Guinée J.B., Gorrée M., Heijungs R., Huppes G., Kleijn R. et al. (2000) Life cycle assessment. An operational guide to the ISO standard, Final report May 2001, Leiden: VROM and CML.

IPCC (Intergovernmental Panel on Climate Change), fourth assessment report. (2007) Changes in human and natural drivers of climate, in working group I report: the physical science basis.

ISO 14040 (2000) Environmental management-life cycle assessmentprinciples and framework, Genève.

ISO 14041 (2000) Environmental management-life cycle assessmentgoal and scope definition and inventory analysis, Genève.

ISO 14042 (2000) Environmental management-life cycle assessmentlife cycle impact assessment, Genève.

ISO 14043 (2000) Environmental management-life cycle assessmentlife cycle interpretation, Genève.

Lombardi L. (2003) Life cycle assessment comparison of technical solutions for $\mathrm{CO}_{2}$ emissions reduction in power generation, Energ. Convers. Manage. 44, 93-108.

Marin G.B., Froment G.F. (1981) Reforming of $\mathrm{C}_{6}$ hydrocarbons on a Pt/Al ${ }_{2} \mathrm{O}_{3}$ catalyst, Chem. Eng. Sci. 37, 759-773.

Meyer L., Tsatsaronis G., Buchgeister J., Schebek L. (2009) Exergoenvironmental analysis for evaluation of the environment impact of energy conversions systems, Energy 34, 75-89.

Meyers R.A. (1999) Handbook of petroleum refining processes, 2nd Edition, McGraw-Hill. Pehnt M., Henkel J. (2009) Life cycle assessment of carbon dioxide capture and storage from lignite power plants, Int. J. Greenhouse Gas Control 3, 49-66.

Portha J.F., Louret S., Pons M.N., Jaubert J.N. (2010) Estimation of the environmental impact of a petrochemical process using coupled LCA and exergy analysis, Resour. Conserv. Recy. 54, 291-298.

Portha J.F., Jaubert J.N., Louret S., Pons M.N. (2008) Definition of a thermodynamic parameter to calculate carbon dioxide emissions in a catalytic reforming process, Int. J. Thermodynamics 11, 81-89.

Renou S., Thomas J.S., Aoustin E., Pons M.N. (2008) Influence of impact assessment methods in wastewater treatment LCA, J. Cleaner Prod. 16, 1098-1105.

Rousseaux P., Apostol T. (2000) Environmental value of energy (in French), Presses polytechniques et universitaires romandes and INSA de Lyon, Lausanne, Switzerland.

Simapro LCA software (2004) Pré Consultants, Simapro 6; 2004. www.pre.nl/simapro/ [accessed 01.02.06].

Simsci-Esscor (2004) Pro II 7.0, United States of America; 2004. www.simsci.com/. [accessed 10.01.06]

Stichnothe H., Azapagic A. (2009) Bioethanol from waste: Life cycle estimation of the greenhouse gas saving potential, Resour. Conserv. Recy. 53, 624-630.

Szargut J. (2005) Exergy method, technical and ecological applications, WIT Press.

Van Trimpont P.A., Marin G.B., Froment G.F. (1988) Reforming of $\mathrm{C}_{7}$ hydrocarbons on a sulfied commercial $\mathrm{Pt} / \mathrm{Al}_{2} \mathrm{O}_{3}$ catalyst, Ind. Eng. Chem. Res. 27, 51-57.

Final manuscript received in September 2010 Published online in October 2010

Copyright (C) 2010 IFP Energies nouvelles

Permission to make digital or hard copies of part or all of this work for personal or classroom use is granted without fee provided that copies are not made or distributed for profit or commercial advantage and that copies bear this notice and the full citation on the first page. Copyrights for components of this work owned by others than IFP Energies nouvelles must be honored. Abstracting with credit is permitted. To copy otherwise, to republish, to post on servers, or to redistribute to lists, requires prior specific permission and/or a fee: Request permission from Documentation, IFP Energies nouvelles, fax.+33147527078, or revueogst@ifpenergiesnouvelles.fr. 


\section{APPENDIX}

Table related to Figure 3: Temperature influence on environmental impacts for $1 \mathrm{~kg}$ reformate (Process 1, naphtha 1, mass allocation)

\begin{tabular}{c|c|c|c|c|c|c|c|c|c|c|c}
\hline Impact & 1 & 2 & 3 & 4 & 5 & 6 & 7 & 8 & 9 & 10 & 11 \\
\hline $\mathrm{T}=770 \mathrm{~K}$ & $1.99 \mathrm{E}-2$ & $1.09 \mathrm{E}-3$ & $3.55 \mathrm{E}-1$ & $4.66 \mathrm{E}-1$ & $4.38 \mathrm{E}-2$ & $4.40 \mathrm{E}-4$ & $2.11 \mathrm{E}-2$ & $6.5 \mathrm{E}-2$ & $2.3 \mathrm{E}-1$ & $1.89 \mathrm{E}-2$ & 9.15 \\
\hline $\mathrm{T}=790 \mathrm{~K}$ & $2.1 \mathrm{E}-2$ & $1.16 \mathrm{E}-3$ & $3.78 \mathrm{E}-1$ & $4.97 \mathrm{E}-1$ & $4.61 \mathrm{E}-2$ & $4.64 \mathrm{E}-4$ & $2.24 \mathrm{E}-2$ & $6.93 \mathrm{E}-2$ & $2.42 \mathrm{E}-1$ & $2.01 \mathrm{E}-2$ & 9.78 \\
\hline $\mathrm{T}=810 \mathrm{~K}$ & $2.18 \mathrm{E}-2$ & $1.2 \mathrm{E}-3$ & $3.92 \mathrm{E}-1$ & $5.17 \mathrm{E}-1$ & $4.76 \mathrm{E}-2$ & $4.81 \mathrm{E}-4$ & $2.32 \mathrm{E}-2$ & $7.2 \mathrm{E}-2$ & $2.5 \mathrm{E}-1$ & $2.08 \mathrm{E}-2$ & 10.16 \\
\hline
\end{tabular}

Table related to Figure 4: Assignment of the three main environmental impacts (Process $1, T=810 \mathrm{~K}$, naphtha 1 , mass allocation)

\begin{tabular}{c|c|c|c}
\hline Impact & Resp. inorganics & Climate change & Fossil fuel \\
\hline Heat furnace & 77.7 & 91.9 & 98.6 \\
\hline Electricity & 22.3 & 7.3 & 1.4 \\
\hline Catalyst regeneration unit & 0 & 0.8 & 0 \\
\hline
\end{tabular}

Table related to Figure 5: Process influence on environmental impacts for $1 \mathrm{~kg}$ of reformate ( $T=810 \mathrm{~K}$, naphtha 1 , mass allocation)

\begin{tabular}{c|c|c|c|c|c|c|c|c|c|c|c}
\hline Impact & 1 & 2 & 3 & 4 & 5 & 6 & 7 & 8 & 9 & 10 & 11 \\
\hline Process 1 & $2.18 \mathrm{E}-2$ & $1.2 \mathrm{E}-3$ & $3.92 \mathrm{E}-1$ & $5.17 \mathrm{E}-1$ & $4.76 \mathrm{E}-2$ & $4.81 \mathrm{E}-4$ & $2.32 \mathrm{E}-2$ & $7.2 \mathrm{E}-2$ & $2.5 \mathrm{E}-1$ & $2.08 \mathrm{E}-2$ & 10.16 \\
\hline Process 2 & $2.16 \mathrm{E}-2$ & $1.18 \mathrm{E}-3$ & $3.87 \mathrm{E}-1$ & $5.08 \mathrm{E}-1$ & $4.76 \mathrm{E}-2$ & $4.81 \mathrm{E}-4$ & $2.32 \mathrm{E}-2$ & $7.2 \mathrm{E}-2$ & $2.49 \mathrm{E}-1$ & $2.06 \mathrm{E}-2$ & 9.98 \\
\hline
\end{tabular}

Table related to Figure 7: Allocation method influence on environmental impacts for $1 \mathrm{~kg}$ of reformate (Process $1, T=810 \mathrm{~K}$, naphtha 1 )

\begin{tabular}{c|c|c|c|c|c|c|c|c|c|c|c}
\hline Impact & 1 & 2 & 3 & 4 & 5 & 6 & 7 & 8 & 9 & 10 & 11 \\
\hline Mass allocation & $2.18 \mathrm{E}-2$ & $1.2 \mathrm{E}-3$ & $3.92 \mathrm{E}-1$ & $5.17 \mathrm{E}-1$ & $4.76 \mathrm{E}-2$ & $4.81 \mathrm{E}-4$ & $2.32 \mathrm{E}-2$ & $7.2 \mathrm{E}-2$ & $2.5 \mathrm{E}-1$ & $2.08 \mathrm{E}-2$ & 10.16 \\
\hline Exergetic allocation & $2.04 \mathrm{E}-2$ & $1.13 \mathrm{E}-3$ & $3.68 \mathrm{E}-1$ & $4.84 \mathrm{E}-1$ & $4.46 \mathrm{E}-2$ & $4.5 \mathrm{E}-4$ & $2.18 \mathrm{E}-2$ & $6.74 \mathrm{E}-2$ & $2.34 \mathrm{E}-1$ & $1.95 \mathrm{E}-2$ & 9.52 \\
\hline
\end{tabular}

